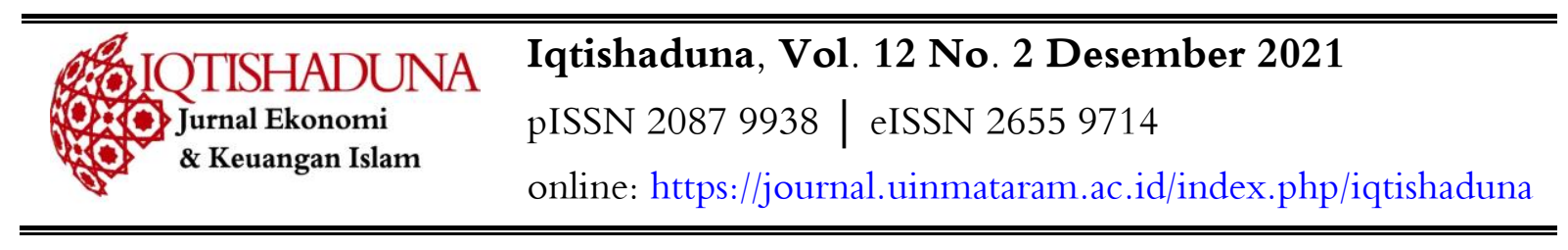

\title{
DEVELOPMENT OF PERFORMANCE IMPROVEMENT OF MSMES IN LOYOK VILLAGE SIKUR DISTRICT EAST LOMBOK REGENCY BASED ON SWOT
}

\author{
ANALYSIS \\ Muhamad Yusup ${ }^{1}$, Triana Lidona Aprilani ${ }^{2}$ \\ muhamadyusup@uinmataram.ac.id ${ }^{1}$, tianalidona0204@gmail.com ${ }^{2}$
}

\begin{abstract}
This study aims to development a SWOT analysis and strategies for improving the performance of MSMEs based on a SWOT analysis. This type of research is descriptive which describes the strengths, weaknesses, opportunities and threats faced by MSMEs in Loyok Village, Sikur District, East Lombok Regency. The type of data used is primary data and secondary data collected by means of documentation, interviews, and in-depth interviews. The research population is all MSMEs actors who are craftsmen, ranging from making baskets, jars, bamboo fans, hats, to skewers and bags whose prices vary. The sample is determined by proportional random sampling. Data were analyzed qualitatively and SWOT analysis. The results show that the strengths of MSMEs are: the availability of raw materials and labor at relatively cheap prices, the quality of the product is very good, the weaknesses of MSMEs are: the number of qualified workers is still low, product designs are less innovative and market information limited opportunities, the opportunities they have are: obtaining capital assistance in the form of soft loans from Village-Owned Enterprises, attention from the government, especially training and assistance and the threats faced by MSMEs are: intense competition and low economic conditions. Four strategies are used to improve the performance of MSMEs based on the results of the SWOT analysis, namely: first, the SO strategy by maintaining product quality by utilizing the assistance of Village-Owned Enterprises and government training, both the WO strategy in compiling online marketing programs and increasing product design innovation and creativity, three strategies ST optimizes the availability of raw materials and relatively cheap labor to win the competition and the four WT strategies increase product design creativity and seek new market share.
\end{abstract}

\section{Keywords: Performance, SMEs, SWOT Analysis}

\section{INTRODUCTION}

Micro, Small and Medium Enterprises (MSMEs) are business units that contribute greatly to development, especially in the form of employment and foreign exchange earners. MSMEs function as the foundation of the Indonesian economy that affects the economy, so the existence of MSMEs must be supported by various programs aimed at developing them, both from the government and the private sector (Bismala, 2014). Small businesses and the informal sector have shown their participation in the national economy in various contributions both in terms of macro and micro (Winarni, 2009). MSMEs have an important role in economic development and growth, 
Yusup \& Aprilani.

not only in developing countries such as Indonesia, but also in developed countries such as Japan, the United States and European countries (Mulyanisman, 2012).

MSMEs need attention from the government, because MSMEs are expected to be able to absorb a lot of energy and have a very large number of business units, with the ability to absorb a large and dominant workforce in this business unit, enabling MSMEs to intensively use local natural resources. The existence of MSMEs, which are generally scattered in rural areas, is expected to have a positive impact on employment in rural areas, equity, income distribution, which can indirectly help the government in alleviating poverty in rural communities, and reducing the movement of people from rural to urban areas which in the end does not directly help the government improve the welfare of rural communities and reduce urban slums. The problems of MSMEs in West Nusa Tenggara (NTB) Province in general are not much different from the problems experienced by MSMEs in Indonesia, namely: low managerial ability (in terms of production, raw materials, administration and finance), low commitment in fulfilling customer orders, (in product design and quality, instability in supply and prices of raw materials or other supporting materials) and low access to financing sources. The government has handled this problem through various empowerment programs for MSMEs, in the form of funding, partnerships, training, mentoring, and others, but empirical facts show that MSMEs in Bali have not developed optimally (Wimba, 2015).

The existence of MSMEs in NTB Province as one of the supporters of the tourism sector is preferred in increasing regional income. The role of MSMEs in this case is to provide added value to increase tourism attractiveness, assist the government in providing tourism facilities and infrastructure, which in turn also contributes to increasing tourism in domestic and foreign tourism. In general, most MSMEs produce products in the form of souvenirs and food for tourists visiting NTB. The development of MSMEs in NTB Province in 2018, is presented in Table 1 below.

Table 1. Development of MSMEs in NTB Province in 2018

\begin{tabular}{llccccc}
\hline No & District/City & \multicolumn{3}{c}{ Business Classification } & \multicolumn{2}{c}{ Total } \\
& & Micro & Small & Medium & Large & \\
\hline $\mathbf{1}$ & Mataram & 46,328 & 11,007 & 632 & 179 & 58,146 \\
$\mathbf{2}$ & Lombok Barat & 110,322 & 10,286 & 461 & 34 & 121,103 \\
$\mathbf{3}$ & Lombok Utara & 7,037 & 369 & 2 & & 7,408 \\
$\mathbf{4}$ & Lombok Tengah & 121,636 & 7,445 & 321 & 28 & 129,430 \\
$\mathbf{5}$ & Lombok Timur & 144,029 & 16,266 & 904 & 62 & 161,261 \\
$\mathbf{6}$ & Sumbawa Barat & 14,898 & 1,651 & 84 & 19 & 16,652 \\
$\mathbf{7}$ & Sumbawa & 40,620 & 6,6661 & 231 & 40 & 47,552 \\
$\mathbf{8}$ & Dompu & 26,558 & 2,019 & 69 & 11 & 28,657 \\
\hline
\end{tabular}




\begin{tabular}{ccccccc}
\hline No & District/City & \multicolumn{3}{c}{ Business Classification } & \multicolumn{2}{c}{ Total } \\
& & Micro & Small & Medium & Large & \\
\hline $\mathbf{9}$ & Bima & 48,952 & 4,535 & 107 & 17 & 25,611 \\
$\mathbf{1 0}$ & Kota Bima & 22,267 & 2,713 & 163 & 24 & 25,167 \\
& Jumlah & 582,647 & 62,952 & 2,974 & 414 & 648,987 \\
\hline
\end{tabular}

Source: BPJS Provinsi NTB (2019)

The data in Table 1 shows that the number of business classifications, whether micro, small, medium, and large, continues to increase. But the absorption of labor, the value of investment, and the value of production decreased. This shows that in general the performance of MSMEs in NTB Province has decreased, so it needs to be critically examined with anticipatory steps so as not to cause more serious problems. The following is the number of Workers in Micro and Small Industrial Enterprises/Companies according to the Standard Classification Code of Indonesian Business Fields, Gender, and Age Group of Workers, 2019 in Table 2.

Table 2. Number of Workers in Micro and Small Industrial Enterprises/Companies according to the Standard Classification Code of Indonesian Business Fields, Gender, and Age Group of Workers, in 2019

\begin{tabular}{|c|c|c|c|c|c|c|c|c|c|c|c|c|}
\hline \multirow{3}{*}{$\begin{array}{l}\text { Kode Klasifikasi } \\
\text { Baku Lapangan } \\
\text { Usaha Indonesia*) }\end{array}$} & \multicolumn{4}{|c|}{ Laki-Laki } & \multicolumn{4}{|c|}{ Perempuan } & \multicolumn{4}{|c|}{ Jumlah } \\
\hline & \multicolumn{4}{|c|}{ Kelompok Umur Pekerja } & \multicolumn{4}{|c|}{ Kelompok Umur Pekerja } & \multicolumn{4}{|c|}{ Kelompok Umur Pekerja } \\
\hline & $\begin{array}{c}=15 \\
\text { Tahun }\end{array}$ & $\begin{array}{l}15-49 \\
\text { Tahun }\end{array}$ & $\begin{array}{l}50-64 \\
\text { Tahun }\end{array}$ & $\begin{array}{c}\equiv 65 \\
\text { Tahun }\end{array}$ & $\begin{array}{c}=15 \\
\text { Tahun }\end{array}$ & $\begin{array}{l}15-49 \\
\text { Tahun }\end{array}$ & $\begin{array}{c}50-64 \\
\text { Tahun }\end{array}$ & $\begin{array}{c}\equiv 65 \\
\text { Tahun }\end{array}$ & $\begin{array}{c}=15 \\
\text { Tahun }\end{array}$ & $\begin{array}{c}15-49 \\
\text { Tahun }\end{array}$ & $\begin{array}{l}50-64 \\
\text { Tahun }\end{array}$ & $\begin{array}{c}265 \\
\text { Tahun }\end{array}$ \\
\hline (1) & $(2)$ & (3) & $(4)$ & (5) & $(6)$ & $(7)$ & $(8)$ & (9) & $(10)$ & (11) & $(12)$ & {$[13)$} \\
\hline 10 & - & 11927 & 3816 & 133 & 171 & 22670 & 5151 & 689 & 171 & 34597 & 8967 & 822 \\
\hline 11 & - & 1145 & 123 & 5 & - & 149 & & 58 & - & 1294 & 123 & 63 \\
\hline 12 & 19 & 36005 & 5303 & 483 & 585 & 42473 & 8894 & 417 & 604 & 78478 & 14197 & 900 \\
\hline 13 & - & 414 & 45 & 16 & - & 7690 & 2713 & 34 & - & 8104 & 2758 & 50 \\
\hline 14 & - & 993 & 255 & 102 & - & 3698 & 997 & 410 & - & 4691 & 1252 & 512 \\
\hline 15 & - & 10 & 2 & 1 & - & 6 & - & - & - & 16 & 2 & 1 \\
\hline 16 & 2 & 22532 & 7423 & 235 & 19 & 23513 & 10259 & 1887 & 21 & 46045 & 17682 & 2122 \\
\hline 17 & . & . & . & - & . & . & . & . & . & 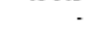 & . & . \\
\hline 18 & - & 736 & 8 & - & . & 26 & - & - & - & 762 & 8 & . \\
\hline 20 & - & 30 & 37 & 7 & - & 15 & 22 & 7 & - & 45 & 59 & 14 \\
\hline 21 & - & 363 & - & o. & - & 598 & 24 & 21 & - & 961 & 24 & 21 \\
\hline 22 & - & 8 & & 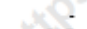 & - & - & - & - & - & 8 & & \\
\hline 23 & 433 & 10628 & 4047 & 217 & 126 & 9075 & 2547 & 135 & 559 & 19703 & 6594 & 352 \\
\hline 24 & - & - & - & - & - & - & - & - & - & - & - & - \\
\hline 25 & 1 & 3588 & 171 & 231 & - & 63 & 12 & - & 1 & 3651 & 183 & 231 \\
\hline 26 & - & . & . & . & - & . & - & - & . & . & - & . \\
\hline 27 & - & - & - & - & - & - & - & - & - & - & - & - \\
\hline 28 & - & 1 & - & - & - & - & - & - & - & 1 & - & . \\
\hline 29 & - & . & - & . & - & - & - & - & - & . & - & . \\
\hline 30 & - & 16 & 6 & - & - & . & - & - & - & 16 & 6 & - \\
\hline 31 & 60 & 2253 & 738 & 123 & . & 133 & 4 & . & 60 & 2386 & 742 & 123 \\
\hline 32 & 13 & 486 & 85 & 62 & - & 324 & 243 & 81 & 13 & 810 & 328 & 143 \\
\hline 33 & - & 219 & - & - & - & - & - & - & - & 219 & - & - \\
\hline Jumlah & 528 & 91354 & 22059 & 1615 & 901 & 110433 & 30866 & 3739 & 1429 & 201787 & 52925 & 5354 \\
\hline
\end{tabular}

Source: East Lombok Regency BPJS, Year 2019

Table 2 shows that IMK businesses in NTB Province absorb as many as 261,495 workers and more than 60 percent are female workers. If you look at the distribution of the number of workers, IMK workers on the island of Lombok are 223,086 people (85.31 percent) and the 
Yusup \& Aprilani.

remaining 38,409 people (14.69 percent) are on the island of Sumbawa. This is reasonable because more than 80 percent of the number of IMKs are on the island of Lombok so that the number of workers is also greater. An in-depth analysis of the low performance of MSMEs in Loyok Village, Sikur District is important to do, to find out the weaknesses and opportunities available to improve performance in the following year. One of the analytical tools that can be used to analyze the existence of MSMEs in Loyok Village, Sikur District, East Lombok Regency is a SWOT analysis.

MSMEs in East Lombok Regency consist of 55 types of businesses, grouped into: (1) Craftsmen group consisting of woven craftsmen (eating, bamboo), coconut shell craftsmen, wood carvings, silver crafts, mini jukung craftsmen, and wooden sculptures, (2) Business groups building materials consist of concrete brick industry, brick, padas, taro and trellis/iron fence, (3) food and beverage group consisting of dodol food industry, Balinese snacks, crackers, salt, brown sugar, peanuts, chips, fermented soybean cake, cassava cakes, rice flour, fish processing, coconut oil, packaged drinks, palm wine processing and food stalls, (4) Textile group consisting of embroidery, screen printing, weaving of garbage bags, convection/tailor and clothing, and (5) Other industries consisting of pillows, kites, paintings, knives and photo copies.

The results of interviews with industry employees and the trade office of Loyok Village, Sikur Subdistrict, show that the craftsman industry group most often receives assistance and support from the government, because this group produces tourism supporting products in the district and absorbs relatively more workers. This condition encourages the SWOT analysis of MSMEs in Loyok Village, Sikur District to focus on groups of craftsmen, weaving, woven bamboo, coconut shells and wood carvings.

\section{LITERATURE REVIEW}

The definition of MSMEs set by BPS (Central Statistics Agency) is based on the number of workers, for small businesses there are five to nineteen people, while for medium-sized businesses it ranges from twenty to ninety-nine workers (Rahmana, 2009). The definition of MSMEs above is in accordance with the MSMEs definition applied to the Asian Development Bank (ADB) (Larasati, 2011). MSMEs have special characteristics that distinguish them from other types of large businesses, including characteristics that distinguish micro-enterprises, small-scale businesses, and medium-sized businesses themselves. More than a third of MSMEs in Indonesia (34.5 percent) are managed by workers aged over 45 years, and only about 5.2 percent of MSMEs entrepreneurs are under 25 years old (Tambunan, 2009). The workforce needed by small industries does not require high formal education. Most of the workforce needed by industry is based on experience (learning by doing) related to historical factors (path dependence) (Sulistyastuti, 2004). 
The entrepreneurial structure according to formal education level shows that there is a positive relationship between the average entrepreneurial education level and business scale, which means that the larger the business scale, which is generally positively related to the level of business complexity that requires high skills and broader business insight, more and more entrepreneurs with tertiary formal education (Tambunan, 2009). Most MSME entrepreneurs reveal the reasons for their business activities having an economic background, meaning that this business is carried out as an effort to increase income and or is a strategy to survive, this condition is caused by the low level of entrepreneurial education.

The MSMEs business is carried out on the grounds that there is no other type of work that can be done with a relatively low level of formal education (Tambunan, 2009). Some entrepreneurs run their business considering the future prospects of the business, such as the existence of a secure and large opportunity and market share, however, others reveal a hereditary background, which means continuing the family heritage business. Indonesia has many MSMEs, but not all of these MSMEs are legal entities, most of the existing MSMEs, which is about 95.1 percent of the number of business units that are not legal entities, this condition is acceptable on the grounds that most MSMEs have minimal capital and adequate regulations. complicated to get services in business development. The characteristics of MSMEs are the use of local raw materials. The existence of MSMEs is often associated with the high intensity of use of local raw materials, for example MSMEs crafted Jepara carving furniture typical of batik from Pekalongan and various other superior local commodities that are used as raw materials in business (Sulistyastuti, 2004).

Performance can be in the form of individual performances or group work. The performance description involves three important components, namely: objectives, measures and assessments. Determining the goals of each organizational unit is a strategy to improve performance. This goal will provide direction and influence on how work behavior should be expected by the organization for each personnel. Even so, goal setting is not enough, because it requires a measure of whether a person has achieved the expected performance. Factors that affect performance are abbreviated to Achieve which means Ability (ability that can be developed), Capacity (defined/limited abilities), Assistance (assistance for performance realization), Incentives (material and non-material incentives), Environment (employee work environment), Validity (guidelines/instructions and job descriptions) and Evaluation (work feedback) (Notoatmodjo, 2009). Performance is a contextual concept related to the phenomenon being studied, so the measures used to represent performance are selected based on the observed state of the company. Performance appraisal is an important activity for the company as a process of evaluating all its activities. Performance appraisal is often a problem because performance appraisal is only intended 
Yusup \& Aprilani.

to evaluate and exclude other goals such as the goal of developing competence and individual goals in carrying out tasks and other goals.

\section{SWOT Analysis}

SWOT analysis is an analytical technique that identifies various factors systematically to formulate strategies. This analysis is based on logic that can maximize strengths and opportunities but at the same time minimize weaknesses and threats (Lestari, 2014). SWOT analysis is generally used to evaluate opportunities and challenges in the company's internal and business environment (Rahmana et al. 2017). The construction of a SWOT matrix is needed to facilitate the implementation of a SWOT analysis, by combining the factors of strength, weakness, opportunities and threats: The SWOT matrix consists of analysis of: (a) SO (StrengthOpportunities) is to use internal strengths to take advantage of external opportunities, (b) WO (Weakness-Opportunities) which aims to improve internal weaknesses by taking advantage of external opportunities, (c) ST (Strength-Threats) by using internal strength to avoid or reduce the influence of external threats, (d) W'T (Weaknesses-Threats) is a defensive strategy directed at reducing internal weaknesses and avoiding internal threats. The preparation of the SWOT matrix consists of eight steps that must be carried out, namely: (a) writing external opportunities, (b) writing external threats, (c) writing internal strengths, (d) writing internal weaknesses, (e) match internal strengths with external opportunities and record SO strategies in the specified cells, (f) match internal weaknesses with external opportunities and record WO strategies in the specified cells, (g) match internal strengths with external threats and record ST strategies in the specified cells, (h) matched internal weaknesses with external threats and recorded WT strategies in defined cells (Amalia et al. 2017). The SWOT matrix is presented in Table 3.

Tabel 3. Matrix of SWOT Analysis

\begin{tabular}{lll}
\hline $\begin{array}{c}\text { Internal Factor } \\
\text { External Factor }\end{array}$ & \multicolumn{1}{c}{$\begin{array}{c}\text { Strengths (S) } \\
\text { (List All Of Strengths) }\end{array}$} & $\begin{array}{c}\text { Weakness (W) } \\
\text { (List All Of Weakness) }\end{array}$ \\
\hline Opportunities (O) & Strategi SO & Strategi WO \\
(List All Of Opportunities) & (Growth) & (Stability) \\
Threats (T) & Strategi ST & Strategi WT \\
(List All Of Threats) & (Diversification) & (Defend) \\
\hline
\end{tabular}

Rabmana, et al (2017)

There are four strategies that can be identified from the SWOT analysis matrix presented in Table 3, namely: the first SO strategy which is a strategy to use all the strengths you have to take advantage of opportunities. Second, the WO strategy is a strategy to overcome all weaknesses by taking advantage of existing opportunities. Third, the ST strategy, which is a strategy to use all 
strengths to avoid threats. Fourth, the WT strategy is a strategy to suppress all weaknesses and prevent all threats.

\section{METHODOLOGY}

This research is a descriptive research, namely research to determine the value of independent variables, either one or more variables (independent) without making comparisons, or connecting with other variables (Sugiyono, 2009). This type of research is descriptive which describes the strengths, weaknesses, opportunities and threats faced by SMEs in Loyok Village, Sikur District. The types of data used in this study consisted of: primary data, namely data on the strengths, weaknesses, opportunities and threats faced by MSMEs in Loyok Village, Sikur District and information about the groups of Craftsmen who most often received training/guidance from the Industry and Trade District Office. Karangasem. Secondary data is data on MSMEs in NTB Province obtained from the NTB Provincial Industry and Trade Office, data on MSMEs in Loyok Village, Sikur District obtained from the East Lombok Regency Industry and Trade Office.

The data collection techniques used in this study are: documentation, the data obtained by the documentation method in this study is the data of MSMEs in NTB Province and in Loyok Village, Sikur District. Interviews in this study were conducted with the head of the MSME data collection section in Loyok Village, Sikur District. Types of interviews conducted: in-depth interviews, researchers conducted in-depth interviews through semi-formal interviews with research informants, they were owners of MSMEs, especially craftsmen of weaving, woven bamboo, coconut shells and wood carvings. The population is all woven craftsmen, woven bamboo, coconut shell craftsmen and wood carving craftsmen in Loyok Village, Sikur District. Determination of the sample is done by proportional random sampling, which is a sampling method based on the representation of the population distribution in each sub-group, then selecting at the next stage the sample members are randomly selected. Determination of the sample using probability sampling, especially proportional random sampling, using the Slovin formula, the calculation of the number of samples in this study is as follows.

$$
n=\frac{N}{1+N e^{2}}
$$

Notes:

$\mathrm{N}=$ Total population

$\mathrm{n}=$ Number of samples

$\mathrm{e}=$ fault tolerance 
Yusup \& Aprilani.

Data from the Department of Industry and Trade of East Lombok Regency shows that the number of woven, woven bamboo, coconut skin and wood carving craftsmen in Loyok Village, Sikur District is 1,415 business units, then using the Slovin formula with an error rate of 10 percent, the number of samples becomes:

1.415

$$
\mathrm{n}=\text {--------- } \mathrm{n}=93
$$

The results of the calculation show that the sample size is 93 units of woven food craftsmen, woven bamboo, coconut shells and wood carvings, using proportional random sampling clusters, proportional sample distribution in each cluster or area, names of sub-districts and groups of craftsmen in Sikur District are presented in Table 4 and Table 5 below.

Table 4. Distribution of Population and Sample in Each District and Each Craft Group

\begin{tabular}{|c|c|c|c|c|c|c|}
\hline \multicolumn{2}{|c|}{ Name Of District } & \multicolumn{2}{|c|}{$\begin{array}{l}\text { Type of craftmen } \\
\text { (unit) }\end{array}$} & $\begin{array}{l}\text { Number Of } \\
\text { Population }\end{array}$ & \multicolumn{2}{|c|}{$\begin{array}{l}\text { Number Of } \\
\text { sampel }\end{array}$} \\
\hline \multicolumn{2}{|c|}{ Ate Plaiting } & \multicolumn{2}{|c|}{ Bamboo Plaiting } & Coconut Shell & \multicolumn{2}{|c|}{ Wood Carving } \\
\hline Semaya & 1 & 24 & 151 & 11 & 187 & $5^{\circ}$ \\
\hline Montong & 53 & 493 & 26 & 101 & 673 & 19 \\
\hline Sikur & 0 & 2 & 0 & 12 & 14 & 0 \\
\hline Loyok & 1.308 & 55 & 3 & 19 & 1.385 & 39 \\
\hline Kotaraja & 134 & 567 & 0 & 26 & 727 & 21 \\
\hline Tetebatu & 72 & 47 & 0 & 25 & 144 & 4 \\
\hline Kembang & 0 & 185 & 0 & 13 & 198 & 6 \\
\hline \multicolumn{7}{|l|}{ Kuning } \\
\hline Gelora & 68 & 6 & 1 & 12 & 87 & 3 \\
\hline Total & 1.636 & 1.379 & 181 & 219 & 3.415 & 97 \\
\hline
\end{tabular}
in Sikur District

Source: East Lombok Regency Industry and Trade Office, 2018 (data processed)

The distribution of samples for each type of industry in each sub-district is presented in Table 5.

\begin{tabular}{|c|c|c|c|c|c|}
\hline \multicolumn{2}{|c|}{ Name Of Regency } & \multicolumn{2}{|c|}{ Type Of Craftmen (unit) } & \multicolumn{2}{|c|}{ Total } \\
\hline Ate & & Bamboo Plaiting & Coconut Shell & & Wood Carving \\
\hline \multicolumn{6}{|l|}{ Plaiting } \\
\hline Semaya & 0 & 1 & 4 & 0 & 5 \\
\hline Montong & 1 & 14 & 1 & 3 & 19 \\
\hline Sikur & 0 & 0 & 0 & 0 & 0 \\
\hline Loyok & 37 & 2 & 0 & 1 & 39 \\
\hline Kotaraja & 4 & 16 & 0 & 1 & 21 \\
\hline Tetebatu & 2 & 1 & 0 & 1 & 4 \\
\hline
\end{tabular}

Table 5. Sample distribution for each type of industry in each Sikur District 


\begin{tabular}{lccccc}
\hline $\begin{array}{l}\text { Name Of Regency } \\
\text { Ate }\end{array}$ & \multicolumn{2}{c}{$\begin{array}{c}\text { Type Of Craftmen (unit) } \\
\text { Plaiting }\end{array}$} & Bamboo Plaiting & Coconut Shell & Wood Carving \\
$\begin{array}{l}\text { Kembang } \\
\text { Kuning }\end{array}$ & 0 & 6 & 0 & 0 & 6 \\
Gelora & 2 & 0 & 0 & 0 & 3 \\
\hline Total & 46 & 40 & 5 & 6 & 97 \\
\hline
\end{tabular}

Source: Data in Table 4

Distribution of samples in each village and each craftsman proportionally based on the area and type of business with the consideration of providing opportunities for all craftsmen in all districts. The data analysis techniques used in this research are: (1) Descriptive analysis technique with a qualitative approach, namely by providing an overview of data or events based on the facts that arise in the situation and object being investigated, the research process is carried out through measurements with a standard tool is a matrix SWOT, (2) The SWOT matrix analyzes the strengths, weaknesses, opportunities and threats faced by craftsmen, (3) The results of the SWOT analysis are used as the basis for developing models to improve the performance of craftsmen.

\section{RESULTS AND DISCUSSION}

\section{SWOT Analysis on MSME Performance}

MSMEs in Sikur District consist of various types of industrial groups, one of which is a group of craftsmen. The group of craftsmen who most often receive assistance and support from the East Lombok Regency Industry and Trade Office for the reason to produce more products that support tourism and absorb more workers is eating woven craftsmen, woven bamboo, coconut shells and wood carvings. The craftsmen who were the samples of this research were 93 craftsmen consisting of 43 food craftsmen, 40 woven bamboo, 5 coconut shell craftsmen and 5 wood carving craftsmen spread over eight (8) villages in Sikur District. Referring to the steps in preparing the SWOT matrix by Amalia, et al (2017) and based on the results of interviews and indepth interviews with respondents, the SWOT analysis of artisans in Sikur District is as follows:

a) Write down external opportunities.

External opportunities faced by craftsmen in running their business are:

1) Get capital assistance in the form of soft loans from Village Owned Enterprises.

2) A lot of attention from the government in the form of training and mentoring programs.

b) Write down external threats.

The external threats faced by craftsmen in running their business are:

1) Tough competition 
Yusup \& Aprilani.

2) Low economic conditions

c) Write down internal strength.

d) The internal strengths of craftsmen in running their business are:

1) Abundant raw materials at relatively low prices.

2) Labor is always available at relatively low prices.

3) Good product quality.

e) Write down internal weaknesses.

The internal weaknesses of craftsmen in running their business are:

1) The number of qualified workers is still low.

2) Product design is less innovative and tends to be monotonous.

3) Information about the market is still limited.

f) Match internal strengths with external opportunities and record SO strategy in the specified cell.

g) Match internal weaknesses with external opportunities and record the WO strategy in the specified cells.

h) Match internal strength with external threat and record ST strategy in the specified cell.

i) Match internal weaknesses with external threats and record the W'T strategy in the specified cells.

The SWOT matrix for MSME craftsmen prepared based on the steps referred to by Amalia, et al (2017) is presented in Table 6.

\section{MSMEs Performance Improvement Strategy Based on SWOT Analysis}

SWOT analysis is used as a basis for developing models to improve MSMEs performance. SWOT analysis is generally used to evaluate opportunities and challenges in the business environment and in the company's internal environment (Kuncoro, 2005). MSMEs craftsmen in Loyok Village, Sikur District are one of the business units experiencing low performance problems, although compared to other MSMEs, craftsmen are MSMEs that receive the most attention from the local government.

The results of the SWOT analysis of the craftsmen are used as the basis for developing performance improvement strategies. Referring to the results of the SWOT analysis that has been carried out, there are four strategies that can be taken to improve the performance of MSMEs craftsmen in Loyok Village, Sikur District, namely: 
Table 6. MSMEs Matrix SWOT Split in Sikur District

\begin{tabular}{|c|c|c|}
\hline INTERNAL & Strength (S) & Weakness $(\mathbf{W})$ \\
\hline FACTOR & a) Raw materials with & a) The number of qualified \\
\hline OUTSIDE & relatively cheap prices & workforce is still low, \\
\hline \multirow[t]{2}{*}{ FACTOR } & $\begin{array}{l}\text { b) Continue to work at a } \\
\text { relatively low price }\end{array}$ & $\begin{array}{l}\text { b) Product design is less } \\
\text { innovative }\end{array}$ \\
\hline & c) Good product quality & c) Limited market information \\
\hline Opportunity (O) & SO STRATEGY & WO STRATEGY \\
\hline a) get capital assistance in & Utilizing Village Owned & Participate in training and \\
\hline the form of soft loans from & Enterprise funds and & guidance programs conducted \\
\hline Village-Owned Enterprises & optimizing the availability of & by the government to \\
\hline b) Attention from the & manpower to develop & improve the quality of the \\
\hline government, especially & business & workforce and increase \\
\hline $\begin{array}{l}\text { training and mentoring } \\
\text { programs, b) Attention from }\end{array}$ & $\begin{array}{l}\text { Maintaining good quality pf } \\
\text { products by utilizing }\end{array}$ & $\begin{array}{l}\text { product innovation and } \\
\text { creativity kreativitas }\end{array}$ \\
\hline $\begin{array}{l}\text { the government, especially } \\
\text { training and mentoring } \\
\text { programs }\end{array}$ & $\begin{array}{l}\text { government training and } \\
\text { mentoring programs }\end{array}$ & $\begin{array}{l}\text { Develop an online marketing } \\
\text { program by optimizing soft } \\
\text { loans from Village Owned } \\
\text { Enterprise }\end{array}$ \\
\hline Threat (T) & ST STRATEGY & WT STRATEGY \\
\hline a) Fierce competition & Win the competition by & Increase creativity and \\
\hline b) Decline in Economic & producing more quality & product innovation. \\
\hline Conditions & products than competitors. & Looking for new market share \\
\hline & Optimizing the use of & \\
\hline & & \\
\hline & $\begin{array}{l}\text { and labor to survive in low } \\
\text { economic conditions. }\end{array}$ & \\
\hline
\end{tabular}

Source: Interview Results With Craftsmen

a) SO Strategy (Strength-Opportunity)

This strategy seeks to optimize the internal strengths of the business to be able to achieve available external opportunities. The efforts made in this strategy are:

1) Utilizing Village Owned Enterprise funds and optimizing the availability of manpower to develop business.

2) Maintaining good quality pf products by utilizing government training programs.

b) WO (Weakness-Opportunities) Strategy.

This strategy seeks to improve internal weaknesses to achieve external opportunities. The actions taken in this strategy are:

1) Participate in training and guidance programs conducted by the government to improve the quality of the workforce and increase product innovation and creativity.

2) Develop online marketing programs by optimizing soft loans from Village Owned Enterprises. 
Yusup \& Aprilani.

c) ST Strategy (Strength-Threat).

This strategy optimizes internal strengths to deal with external threats. The actions taken in this strategy are:

1) Win the competition by producing more quality products than competitors.

2) Optimizing the use of relatively cheap raw materials and labor to survive in low economic conditions.

d) WT (Weakness-Threat) Strategy.

This strategy minimizes internal weaknesses to deal with external threats. The actions taken in this strategy are:

1) Increase creativity and product innovation.

2) Looking for new market share.

\section{CONCLUSIONS}

The conclusions of the study refer to the results and discussions: (1) the results of the SWOT analysis show the strengths $(\mathrm{S})$ of the craftsman group are: they have raw materials at relatively low prices, labor is always available at relatively low prices, good product quality. Weaknesses of craftsmen are still low in the quality of labor, less innovative product designs and market information is still limited. The available opportunities are to get capital assistance in the form of soft loans from Village-Owned Enterprises, attention from the government in training and mentoring programs. The threats faced by craftsmen are intense competition and low economic conditions. Weaknesses and threats faced by craftsmen motivate craftsmen to keep running their business because on the other hand, craftsmen have the advantage of abundant raw materials at relatively low prices, labor is always available at relatively low prices and good product quality. Another motivator is external opportunities, they are capital assistance funds in the form of soft loans from Village-Owned Enterprises and attention from the government in the form of training and mentoring programs, (2) The results of the SWOT analysis are used as a basis for developing strategies to improve the performance of craftsmen, they are SO strategies to maintain product quality by utilizing Village Owned Enterprises assistance and training from the government, WO strategies to create online marketing programs and increase product design innovation and creativity, ST strategy to optimize the availability of raw materials and relatively cheap labor to win the competition and WT strategy to increase product design creativity and seek new market share.

Research recommendations are addressed to: (1) Craftsmen must make efforts to improve the quality of the workforce by including them in product innovation training and create online 
marketing programs, and (2) The government is expected to continue to carry out training and mentoring programs, training should not focus on the production sector but also in the marketing sector by collaborating with other parties such as universities, Village Owned Enterprises are also expected to continue to fund the craftsman business to promote economic growth in the village.

\section{REFERENCES}

Amalia Alfi, Hidayat Wahyu dan Budiatno Agung. 2017. Analisis Strategi Pengembangan Usaha Pada UKM Batik Semarangan Di Kota Semarang. Jurnal Ilmu Administrasi dan Bisnis. Diponogoro University Semarang.

Bismala, Lila dan Handayani, Susi. 2014. Model Manajemen MSMES Berbasis Analisis SWOT. Naskah Lengkap Seminar Nasional PB3I ITM. Muhamadyah University Sumatera Utara.

Cochran, W. G. 1993. Sampling Techniques. Second Edition, Joha Wiley \& Sons, Inc. New York, Library Of Congress Catalog Card Number: 63-7553.

Cooper, D. Dan Emory C. 1996. Metode Penelitian Bisnis. Edisi Kelima. Jilid 1. Jakarta: Erlangga.

Dawson, Catherine. 2002. A Practical Guide to Research Methods, How To Content. Oxford.

Kuncoro, M. 2005. Strategi: Bagaimana Meraih Keunggulan Kompetitif?, Jakarta: Erlangga.

Larasati, Bio Hafsari. 2011. Analisis Hubungan Komunikasi Pemasaran Dengan Kualitas Daya Saing Usaha Mikero Kecil Dan Menengah (MSMES) (Studi pada MSMES Mitra Binaan IPB). Departemen Sains Komunikasi dan Pengembangan Masyarakat. Fakultas Ekologi Manusia. Institut Pertanian Bogor.

Lestari Ni Putu Nina Eka. 2014. Strategi Pembedrdayaan Industri Kecil Kerajinan Ukiran Kayu di Kabupaten Gianyar Bali. Disertasi. Program Doktor. Program Studi Ilmu Ekonomi. Program Pasca Sarjana. Denpasar: Universitas Udayana.

Mulyanisman. 2012. Analisa Penerapan Akuntansi Keuangan Pada Perusabaan Menengah Bidang Perdagangan. Artikel.

Notoatmodjo, Soekidjo. 2009. Kesehatan Masyarakat "Seni dan Ilmu”. Jakarta: Rineka Cipta

Rahmana Arief, Iriani Yani dan Oktarina Rienna. 2017. Strategi Pengembangan Usaha Kecil menengah Sektor Industri Pengolahan. Artikel. Di akses dari. www. Google cendekia. Download in 21 Mei 2018.

Sugiyono. 2009. Statistik Untuk Penelitian. Bandung: CV Alfabeta.

Sulistyastuti. Dyah Ratih 2004. 'Dinamika Usaha Kecil dan Menengah (UKM Analisis Konsentrasi Regional UKM di Indonesia 1999-2001', Jurnal Ekonomi Pembangunan, Volume 9, Number 2 Desember 2004, page 143-164, Tambunan, Tulus T.H. 2012, UMKM di Indonesia, Ghalia Indonesia, Jakarta 
Yusup \& Aprilani.

Wimba I Gusti Ayu. 2015. Pengaruh Modal Sosial Terhadap Orientasi Kewirausahaan dan Biaya Transaksi Untuk Meningkatkan Kinerja Usaha Pada UKM Kerajinan Kayu di Provinsi Bali. Disertasi. Program Pasca Sarjana Fakultas Ekonomi dan Bisnis Udayana University. Denpasar.

Winarni, Sri. 2009. Menerapkan Penggunaan Laporan laba/rugi Pada Usaha Kecil dan Menengah. Jurnal Ilmiah Akuntansi. Volume I No. 2. 